\title{
Optimum harvesting scenarios for the management of the bigeye tuna Thunnus obesus at the Eastern Pacific Ocean
}

\author{
Escenarios óptimos de manejo para el atún patudo Thunnus obesus \\ en el Océano Pacífico oriental
}

\section{Ernesto A. Chávez ${ }^{1}$ Fabián D. Escobar-Toledo ${ }^{1,2}$ and Sofía Ortega-García ${ }^{1}$}

\author{
${ }^{1}$ Centro Interdisciplinario de Ciencias Marinas del IPN (CICIMAR-IPN), Av. IPN s/n, Col. Playa Palo de Sta. Rita, La Paz, \\ Baja California Sur, CP. 23096, México. echavez@ipn.mx \\ ${ }^{2}$ Laboratorio de Investigaciones Pesqueras Tropicales, Universidad del Magdalena, Santa Marta, Colombia
}

\begin{abstract}
Resumen.- A partir de datos de captura y esfuerzo de la flota atunera de cerco, de parámetros socio-económicos de la pesquería y de parámetros biológicos del patudo (Thunnus obesus) en el Océano Pacífico oriental se reconstruyó la estructura poblacional para el periodo 1995-2009. La mortalidad por pesca en los últimos años indica una creciente presión sobre el stock, pero se encontró que el recurso está ligeramente subexplotado. Mediante el aumento de la mortalidad por pesca y la disminución de la edad de primera captura se alcanzará el Rendimiento Máximo Sostenible (MSY). El máximo rendimiento económico (MEY) puede lograrse reduciendo la edad de primera captura y la tasa de mortalidad por pesca. Con una reducción de esta mortalidad en $20 \%$ anual, e puede recuperar el stock y la razón beneficio/ costo aumentaría permitiendo una pesca sostenible. Los resultados de las simulaciones sugieren que la mejor estrategia de captura a adoptar sería el MEY, que implica varias ventajas y pocos inconvenientes sociales y económicos, que después de una comparación con la condición actual, parecen ser bastante aceptables. De adoptarse, es conveniente aplicarlo gradualmente para evitar un impacto indeseable desde el punto de vista social, porque implicaría una reducción de casi $7 \%$ de los pescadores. La ganancia económica mostró un aumento significativo mayor del $20 \%$, lo cual se podría utilizar para financiar otras actividades económicas que proporcione empleo a los pescadores que dejan esta actividad.
\end{abstract}

Palabras clave: Thunnus obesus, pesquería, Océano Pacífico oriental, escenarios de manejo

\begin{abstract}
Catch and effort data of the tuna purse seine fishery and biological and socio-economic parameters of bigeye tuna (Thunnus obesus) in the Eastern Pacific Ocean were used to reconstruct the population structure for 1995-2009. The fishing mortality in recent years indicates a growing pressure on the stock, but it was found slightly under exploited. By increasing the fishing mortality would allow attaining the Maximum Sustainable Yield (MSY). The Maximum Economic Yield (MEY) can be achieved by reducing the fishing mortality rate. With a reduction of the fishing mortality in $20 \%$ per year, the stock could be restored and the benefit/cost ratio could increase allowing a sustainable fishery. Results of the simulations suggest that the best harvesting strategy to adopt would be at the MEY, which imply several benefits and a few inconvenient social and economic costs, which after a comparison with the current condition, seems to be quite acceptable. If adopted, it is convenient to apply it gradually to avoid undesirable impact from the social point of view, because it would imply a reduction of nearly $7 \%$ of the fishermen. The economic benefit would have a significant increase over $20 \%$, these surplus income could be used to finance other economic activities to provide employment to the fishermen leaving this activity.
\end{abstract}

Key words: Thunnus obesus, fisheries, Eastern Pacific Ocean, management scenarios

\section{INTRODUCTION}

In the Eastern tropical Pacific Ocean (EPO), tuna and other highly migratory fish are caught by various fishing gears, from long lines to purse-seine (Lennert-Cody et al. 2007, FSR 2010). This area of the ocean contributes with about $14 \%$ of the world tuna production (ISSF 2010). Among its key commercial species are yellowfin (Thunnus albacares), skipjack (Katsuwonus pelamis), bigeye
(Thunnus obesus) and albacore (Thunnus alalunga) (FSR 2010). The bigeye is amongst the most important tuna species landed. Bigeye tuna are distributed throughout the Pacific Ocean and it is believed there is only a single stock with a local exchange of individuals (FSR 2010). Numerous stock assessments of bigeye have been made from analysis of old data, capture, length, etc. (Maunder 
\& Watters 2003, Harley \& Maunder 2005, Maunder \& Hoyle 2006) published in reports of the Interamerican Tropical Tuna Commission, IATTC (Maunder \& Harley 2007), indicating that the bigeye stock in the Eastern Pacific was over-exploited (IATTC 2008). However, according to the most recent stock assessment conducted in 2009 (Aires-da Silva \& Maunder 2010), fishing mortality rates are estimated to be below the level corresponding to the Maximum Sustainable Yield (MSY), and the recent levels of spawning biomass are estimated to be above that level (IATTC 2010).

For the management of this fishery, several international agreements have been established e.g., United Nations Convention on the Law of the Sea and the United Nations Fish Stocks, whose main objective is to maintain populations at levels of MSY. However, this goal has the problem of no taking into account the economic aspects or the social ones (Maunder \& Harley 2007). Therefore, the aim of this paper is to evaluate the fishery and simulate different management scenarios taking into account not just the MSY, but also the Maximum Economic Yield (MEY), and the social aspect in terms of the dependence of the number of direct jobs from changes in $F$, including a brief analysis of the cost of fishing and the elasticity of prices and demand.

\section{Materials AND METHODS}

The assessment of the stock was made using 15 years of catch data of the bigeye tuna at the EPO (FSR 2010). The population parameter values were taken from published sources and are indicated in Table 1. Changes in abundance over time were determined using the catch data in metric tons (mt). Trends in fishing mortality $(F)$ over time and the estimates of the stock biomass were examined. The criteria used for evaluation of fishing scenarios were based on the $F$ and the age of first catch (tc). Other reference point examined was the $F$ at the maximum-economic-yield ( $\left.F_{\mathrm{MEY}}\right)$ and the $F$ at the maximum sustainable yield $\left(F_{\text {MSY }}\right)$. The number of direct jobs is a consequence of the former 2 variables and therefore it could not be set as a target in simulations, it is a variable directly depending on the fishing intensity and its maximum value is found at the highest $F$ used as input.

Table 1. Population parameter values used for the evaluation of the big eye tuna exploited in the EPO (FSR 2010). $K, t_{o}, L_{\infty}$ and $W_{\infty}$ are from the von Bertalanffy growth model. $a$ and $b$ are from the length-weight allometric equation; $t c=$ age of first catch; $M=$ Natural mortality; $t m=$ Maturity age; $t_{\lambda}=$ Longevity and $E_{\text {max }}=$ Exploitation rate at the MSY level. The $W_{\infty}$ value was obtained

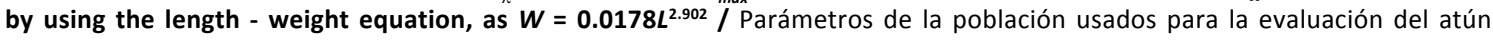
patudo explotado en el OPO (FSR 2010). $K, t_{o^{\prime}} L_{\infty}$ y $W_{\infty}$ fueron obtenidos del modelo de crecimiento de Von Bertalanffy. $a$ y $b$ de la relación longitud-peso; $t c=$ edad de primera captura; $M=$ mortalidad natural; $t m=$ edad de madurez; $t_{\lambda}=\operatorname{longevidad}$ y $E_{\max }=$ tasa de explotación al nivel de RMS. El valor de $W_{\infty}$ fue obtenido usando la relación peso - longitud, como $W=0,0178 L L^{2,902}$

\begin{tabular}{lcll}
\hline Parameter & Value & \multicolumn{1}{c}{ Units-Model } & \multicolumn{1}{c}{ Source } \\
\hline$K$ & 0.23 & Bertalanffy & Zhu et al. (2009) \\
$L_{\infty}$ & 207.4 & cm & Zhu et al. $(2009)$ \\
$W_{\infty}$ & 94,145 & Weight, g & Nakamura \& Uchirama (1996) \\
$t_{o}$ & -0.4 & Years-Bertalanffy & Zhu et al. (2009) \\
$a$ & 0.0178 & Length-weight & Nakamura \&Uchirama (1996) \\
$b$ & 2.92 & Length-weight & Nakamura \&Uchirama (1996) \\
$t c$ & 4 & Years & Compeán (2010) \\
$t m$ & 5 & Years & FISMO \\
$t_{\lambda}$ & 13 & Years & Pauly (1983) \\
$\beta$ & 2.25 & & Beverton \& Holt (1957) \\
$M$ & 0.345 & Instantaneous rate & Jensen (1996, 1997) \\
$E_{\max }$ & 0.25 & $F_{M S Y} /\left(M+F_{M S Y}\right)$ & This paper \\
$P h i^{\prime}$ & 4 & Log $K+2$ Log $L$ & Vakily $(1992) ;$ Sparre \&Venema (1997) \\
Value/Kg & 1.5 & USD & FIS (2013)* \\
Cost/day/trip & 879 & USD & Mora (1997) \\
Cost/Catch & 755 & USD/mt & This paper \\
\hline
\end{tabular}

*FIS. 2013. Precios de Mercado. Reporte septiembre de $2010<$ http://www.fis.com/fis/marketprices/ teechart/framegraph.asp?dollar=False \&market=88\&specie=57\&days=30\&price=min\&graph=11620> 
The population parameters plus the catch data were analyzed with the aid of a simulation model, implemented in the age-structured simulation model FISMO (Chávez 2005). The age of first capture was 3 years and was maintained constant in the fitting process, but for the simulation all the $F$ and tc values feasible to apply were tested in the optimizing process and for designing exploitation policies.

Additionally, the maximum social value was determined in 2 ways. The first one is the maximum level of employment or in other words, the maximum number of fishermen. The second way of the approach consists in evaluating the maximum profit per fisherman. Economic and social values were the value per $\mathrm{kg}$ landed, the number of fishermen per vessel, the number of vessels and the number of fishing days, all from the last fishing season and later estimated for each year of catch data. Costs were obtained by adding the cost/vessel/day times the total number of fishing days of the fleet over the fishing season. Profits were substracted from the total value of the catch minus the total costs. Costs and value were linked to the catch in the FISMO simulation model (Chávez 1996, 2005), which allowed testing all of the possible scenarios of exploitation. The model is based on general principles of fish stock assessment (Hilborn \& Walters 1992).

Population parameter values were known and were taken from the literature (Zhu et al. 2009, Nakamura \& Uchiyama 1966, Table 1), and estimates of the age composition of the catch from the FAO records. In each case total mortality $\left(Z_{t}\right)$ was determined with the exponential decay model as

$$
\mathrm{N}_{a+1}=\mathrm{N}_{a} \mathrm{e}_{t}^{(-\mathrm{z})}
$$

where, $N_{a+1}$ is the number of bigeye fish of age $a+1$ and $N_{a}$ is the number of bigeye fish of age $a$ in reconstructed age-groups. With the use of the von Bertalanffy growth equation describing growth as a function of age, it was possible to determine the numbers per age, using the catch as reference, allowing the determination to their corresponding individual lengths and weights. These lengths were transformed into their respective we.ights by using the equation

$$
W=a \cdot L^{b}
$$

where $W=$ total weight $(\mathrm{g})$ and $L=$ total length $(\mathrm{cm})$.

The time units were years. The age structures for each year were estimated assuming a constant natural mortality. For setting the variables of the initial state, the abundance per age class $\left(N_{a, y}\right)$ was defined using the age-specific abundance $N_{a} / \Sigma N_{a}$ obtained from first equation. In subsequent years, the age structure was defined after the estimation of the number of one-year-old recruits. These values were used to calculate catch-at-age as proposed by Sparre \& Venema (1997) and were integrated into the FISMO simulation model (Chávez 2005) as:

$$
Y_{a, y}=N_{a, y} \cdot W_{a, y} \frac{F_{t}}{\left(F_{t}+M\right)}\left(1-e^{\left(-F_{t}-M\right)}\right)
$$

where, $Y_{a, y}$ is the catch-at-age a of each year $y, N_{a, y}$ is the number of bigeye tunas at age $a$ in year $y, W_{a, y}$ is the fish weight equivalent to $N_{a, y}, F_{t}$ is described, and $M$ is the natural mortality. Given the established initial conditions, the values of $Y_{a, y}$ were adjusted by varying the initial number of recruits and linked to the equations described above until the condition of the following equation was fulfilled:

$$
\sum_{a}^{\lambda} Y_{a, y}=Y_{y(R E C)}
$$

where $Y_{y(R E C)}$ is the yield recorded during the year $y, a=2$ years, $K$ is the growth constant of the von Bertalanffy growth equation, and $t_{\lambda}=3 / K$ or longevity (= 25 years). This value was found by assuming that a reasonable life expectancy $\left(L_{\max }\right)$ is when $95 \%$ of the population reaches $95 \%$ of $L_{\infty}$, the asymptotic length (Chávez 1995). The longevity was found by making $L_{\max }=0.95 L_{\infty}$ in the von Bertalanffy growth equation and finding the respective value of $t$ in the equation. Use of the catch equation was made for each year in the time-series analyzed. For the estimation of the natural mortality $(M)$, the criterion proposed by Jensen $(1996,1997)$ was adopted, where M $=1.5^{*} K=0.1793$ (see Table 1 ); the approach by Gislason et al. (2010) is not too different. Estimations of the stock biomass and the exploitation rate $\mathrm{E}=[F /(M+F)]$ were made for each age-class in every fishing year analyzed by the model. These values were compared to the $\mathrm{E}$ value at the $\mathrm{F}_{\mathrm{MSY}}$ level, corresponding to the maximum exploitation rate that a fishery attains before the stock is over exploited. A diagnosis of which years of the series the stock was under or over exploited was then made, providing an easy way to recommend either a further increase or decrease of $F$.

The annual cohort abundance $\left(N_{a, y}\right)$ coming from ages older than age-at-maturity ( $t m=5$ years) were used to estimate the annual abundance of adults $\left(S_{y}\right)$ over the years, whereas the abundance of the one-year-old group 
was used as the number of recruits $\left(R_{y}\right)$. The stockrecruitment relationship was evaluated by using a slightly modified version of the Beverton \& Holt (1957) model in the form:

$$
R_{y+1}=\frac{\alpha S_{o} S_{y}}{S_{y}+\beta S_{o}}
$$

where $R_{y+1}$ is the number of one-year-old recruits in year $y+1, S_{y}$ is the number of adults in year $y, S_{o}$ is the maximum number of adults in the population, and $a$ and $b$ are: parameters modified from the original model where $a$ is the maximum number of recruits and $b$ is the initial slope of the recruitment line, which was constant through the simulation. Estimates of economic data were made after the report of a comercial trip for 1997 (Mora 1997). The values of the parameters used as input are shown in Table 1.

The bio-economic analysis of the fishery was carried out by following the simplistic approach of assigning a mean cost to each fishing day by a mean-sized vessel, and an account of the days of a typical fishing season, multiplied by the number of vessels; with this information it was possible to have an estimate of total costs. The number of direct jobs, the fishermen, was determined by multiplying the number of fishermen per vessel and then multiplying this number by the total number of vessels. The catch value is usually obtained from statistics, associated to current price of the fish landed and the profits are known by subtracting total value minus total costs in a given fishing season. To relate the costs with $F$, it was necessary to estimate a catchability coefficient based on the $F$ and the fishing effort $(f)$ applied to the last fishing season, when this data were obtained, allowing to estimate $f$ for the 15 years of catch data and to simulate costs and profits for the 30 following years. This way, to a certain $F$ value, there is a number of fishing days, costs, profits, vessels, and a number of fishermen associated, such that in a given fishing season,

Total costs $=Y_{a, y} \mathrm{x}$ cost per fishing day

Total profits $=\left(Y_{a, y} \mathrm{x}\right.$ value per $\left.\mathrm{kg}\right)$ - Total Costs

Number of vessels $=F /(\mathrm{q} f)$

Number of fishermen $=$ Number of vessels $\mathrm{x}$ Number of fishermen per vessel

Number of fishing days $=$ Number of vessels $\mathrm{x}$ Number of fishing days in the season

The bio-economic model was developed in Excel, where with the aid of the some macros, it was possible to obtain a wide number of output variables that allowed to evaluate many numerical and graphical harvesting scenarios, where the most important ones are the trend lines of catch, profits, stock biomass, number of direct jobs (the fishermen), the number of vessels, and the benefit/cost ratio. In most cases, for a given $t c$, the graphic output describes asymmetrical curve lines, where there is a maximum value at a given $F$; from these outputs, it is particularly important to mention that the Yield and the profits attain a maximum value at a certain $F$ value, corresponding to the maximum yield at $F_{M S Y}$ or maximum sustainable yield, and the maximum profits at $F_{M E Y}$ or the maximum economic yield. In most cases, the last one $\left(F_{M E Y}\right)$ is attained at an $F$ value that is lower than the one required for the $F_{M S Y^{*}}$. In some cases, particularly in valuable fisheries, the $F_{M E Y}$ is at a higher value than the $F_{M S Y}$, or at the same $F$ value, but never higher.

The bioeconomic analysis of the fishery was made as far as the landing time, not afterwards, so no added value was considered. Cost of catch was determined simply as a division of total costs, divide by total catch, both in a given time. Correspondence between $f$ and $F$ was made, to estimate the cost per fishing day in reference to the last year of catch records.

Elasticity of prices and demand was taken into account by adding 5 and $10 \%$ to current fishing cost, and adding the same proportions to catch value; impact of these inputs was determined on total profits, on the cost of catch, and on the Benefit/Cost ratio.

Results of simulation are based only in the long-term output, not on the transition period immediately after the historical records; it was done this way because in cases of over exploitation of long-lived species, restoration of stocks may take more than 10 years. For this reason, any exploitation scenario indicated in the section of results should consider a gradual application of any changes of $F$, not shown here, to avoid unexpected results inconsistent with the simulated outputs.

\section{RESULTS}

From the generalized simulation model of a fishery (FISMO), age structure and catch for the last 15 years of data (1995-2009) were reconstructed. The catches range between $25 \%$ and $40 \%$ of the stock biomass (Fig. 1), which shows that the stock is under-exploited and close to the MSY level. The rate of exploitation $(F / Z)$ also confirms this trend. The last years of the simulation reveal a relative stability in the stock biomass with some fluctuations at the beginning of the time series (Fig. 1). The trend of $F$ 
a)

b)
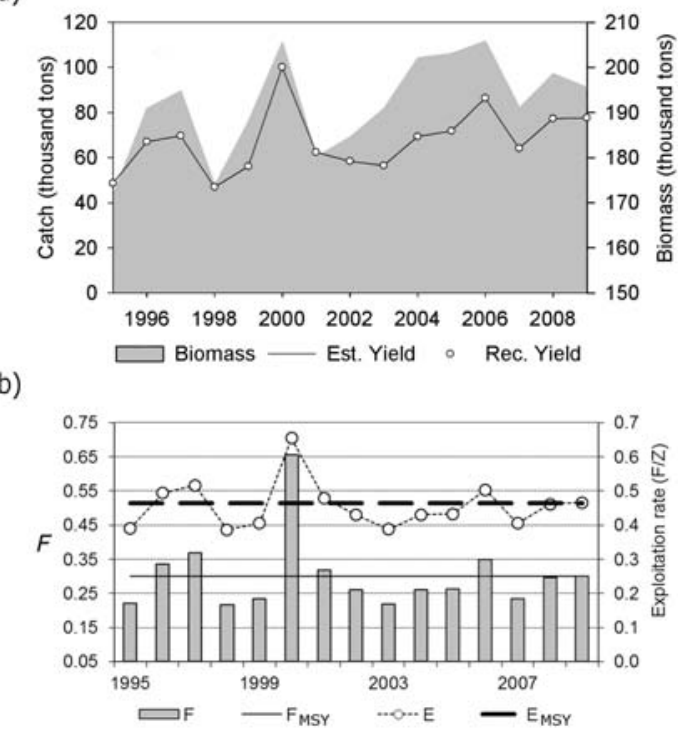

c)

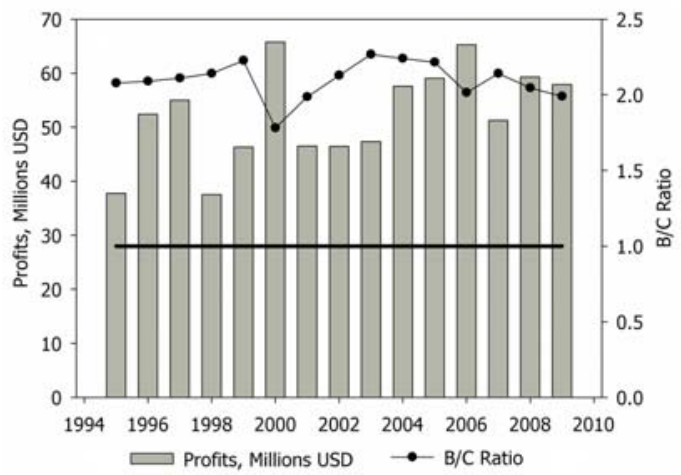

Figure 1. a) Estimated stock biomass (area, right scale) and catch (solid line, left scale), from data after the IATTC; b) exploitation rate $(E)$ and fishing mortality $(F)$ of the Thunnus obesus fishery; $c$ ) Profits (bars, left scale, USD) and Benefit/Cost ratio (line, right scale) of the big eye tuna fishery at the EPO, estimated after the simulation model / a) Biomasa (área, eje derecho) y captura (línea, eje izquierdo) estimados a partir de datos de captura de la IATTC; b) Tasa de explotación $(E)$ y mortalidad por pesca $(F)$ en la pesquería de Thunnus obesus; c) Utilidades (barras, eje izquierdo, Dólares) y tasa Beneficio/Costo (línea, eje derecho) de la pesquería del atún patudo en el OPO, estimado con el modelo de simulación

and the exploitation rate in the 15 years of the analysis (Fig. 1b) indicates that the population is under exploited, i.e., in the case of $F$, in only 3 years the values were exceeded, particularly during the 2000 season; in the seasons 1996 and 1997, a moderate over-exploitation was observed (should not be $F>0.29$ ). The trend of the exploitation rate values $(E)$ are more consistent and only in 2000 exceed the limit of $E=0.46$. The profits of this
Table 2. Management scenarios for the big eye tuna (Thunnus obesus) fishery at the EPO. The age of first catch is 4 years, the same as in the fishery / Escenarios de manejo para la pesquería del atún patudo (Thunnus obesus) en el OPO. La edad de primera captura es 4 años, igual que en la pesquería

\begin{tabular}{lccc}
\hline Indicators & Current & $F_{\text {MSY }}$ & $F_{\text {MEY }}$ \\
\hline Stock biomass, mt & 736,130 & 675,546 & 903,724 \\
$F$ (/yr) & 0.249 & 0.29 & 0.16 \\
Age first catch & 4 & 4 & 4 \\
Yield (mt) & 77,605 & 78,206 & 69,870 \\
Fishing days/yr & 66,685 & 77,665 & 42,850 \\
Days/vessel/yr & 304 & 304 & 304 \\
Vessels & 219 & 274 & 219 \\
Direct jobs & 3,517 & 3,572 & 2,852 \\
Catch value & $116,407,500$ & $117,309,279$ & $104,805,550$ \\
Total Costs & $58,616,233$ & $68,267,902$ & $37,665,049$ \\
Costs/Catch, USD/mt & 755 & 873 & 539 \\
B/C & 1.99 & 1.72 & 2.78 \\
Profits & $57,791,267$ & $49,041,377$ & $67,140,501$ \\
Profits/vessel & 213,907 & 178,740 & 306,578 \\
Profits/Fisherman & 16,431 & 13,730 & 23,542 \\
\hline
\end{tabular}

activity (Fig. 1c) indicate that this is a very productive fishery, for even considering the bigeye as the target species, the fleet generates profits that in half of the study period are over $40 \mathrm{M} U S D$, with a benefit/cost ratio (B/C) $>1.9$, indicating that it is a healthy economic activity.

The simulation of different management scenarios proposed (MSY, MEY and direct jobs) to ensure a full biological and economic exploitation, shows that the fishery $(F=0.249$ ) shows higher profits at the current state than at the MSY level (Table 2). The MSY is attained at $F=0.29$ and the $M E Y$ at $F=0.16$ maintaining the same age of first catch of 4 years in all cases (Fig. 2). To achieve the level of $M E Y$, the $F$ should be reduced from the current value of 0.249 to 0.16 . In principle, this would be the best management scenario because it would generate the highest profits of the fishery and the highest income per fisherman; it would imply a reduction of the fishing effort by about $30 \%$ which would result in a reduction of the catch in nearly 8,000 mt (Table 2 ).

The elasticity of prices and value were examined by adding 5 and $10 \%$ to catch value and to the cost of fishing, as was stated before. The effect of these changes was evaluated in the profits (Fig. 3a), in the cost of catch (Fig. $3 b$ ), and in the $\mathrm{B} / \mathrm{C}$ ratio (Fig. $3 \mathrm{c}$ ), as a function of $F$. In the 3 cases the 5 and $10 \%$ additions are represented as lines thinner than the current trend, which is shown as a thicker line in each case. 
a)

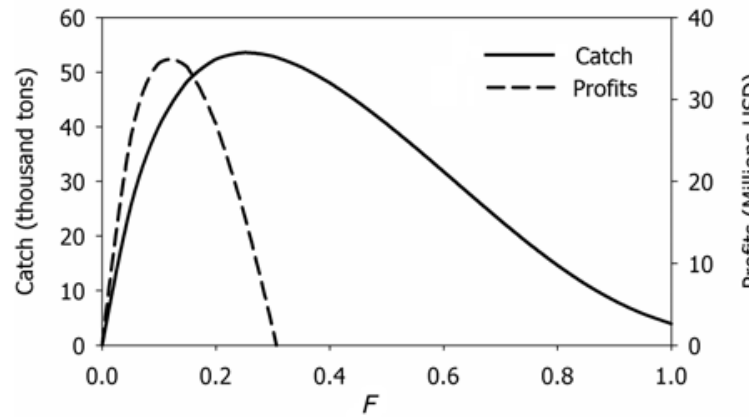

b)

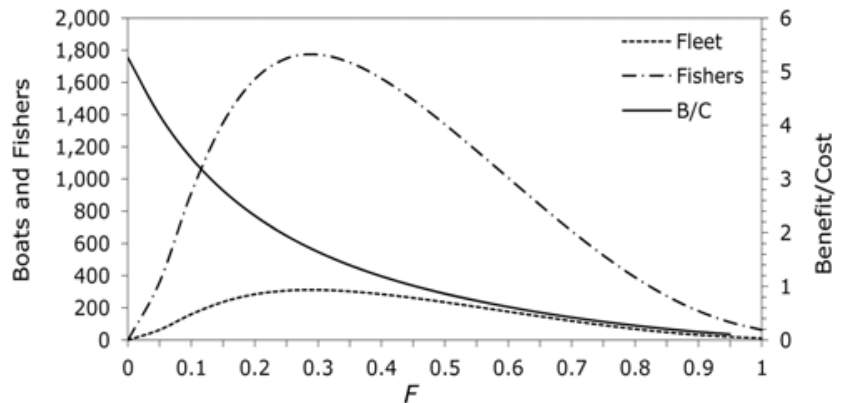

Figure 2. a) Potential yield (mt) and profits (millions USD) of the Thunnus obesus fishery; b) Benefit/Cost ratio, number of fishermen, and number of vessels as a function of $\boldsymbol{F}$ / Rendimiento potencial (mt) y utilidades (millones de USD) de la pesquería de Thunnus obesus; b) Tasa Beneficio/Costo, número de pescadores y número de barcos en función de $F$

The potential profits as a function of $F$ describe a curve concave downward (Fig. 3a); the $F_{M E Y}$ is found at $F=$ 0.16 , and evidences a stronger effect of catch value than similar increases of the cost. The differences respect to current trend are bigger in $F \geq F_{M E Y^{\circ}}$ On examining the cost of fishing, this variable increases nearly 4 times as a function of $F$; at $F$ values ranging from 0.05 to 0.5 . At the current fishing intensity, the cost of fishing is \$ 755 USD per mt, and \$ 873 at the MSY; it is not sensible to increases in catch value (Fig. $3 \mathrm{~b}$ ). When the $\mathrm{B} / \mathrm{C}$ ratio was examined, the response of this variable describes a decreasing curve respecting to $F$ ranging from 4.5 at $F=0.5$, to 0.8 at $F=$ 0.5 . In this case, the 5 and $10 \%$ increase of cost and catch value display a symmetric range respecting to the mean trend (Fig. 3c).

\section{Discussion}

Results show that the current status of the resource is evidence of recent efforts to maintain an adequate status of the stock of bigeye tuna in the EPO, according to the most recent assessment (Maunder \& Hoyle 2006, IATTC 2010), indicating that fishing mortality is still appropriate to maintain a sustainable fishery despite increasing captures of young fish in fish aggregating devices (FSR 2010). Continuation of these regimes and forms of exploitation may be causing an evolutionary change in the size and age-strusture of populations, decreasing the size and average age of capture (Shin et al. 2005), and may modify the predator-prey interactions (Froese et al. 2008) affecting the stability of the community and pelagic ecosystem where the bigeye tuna belongs (Bascompte et al. 2005). This could aggravate the potential reduction of the MSY level affecting the economic value of this fishery over the long term (Trexler \& Travis 2000). However, at

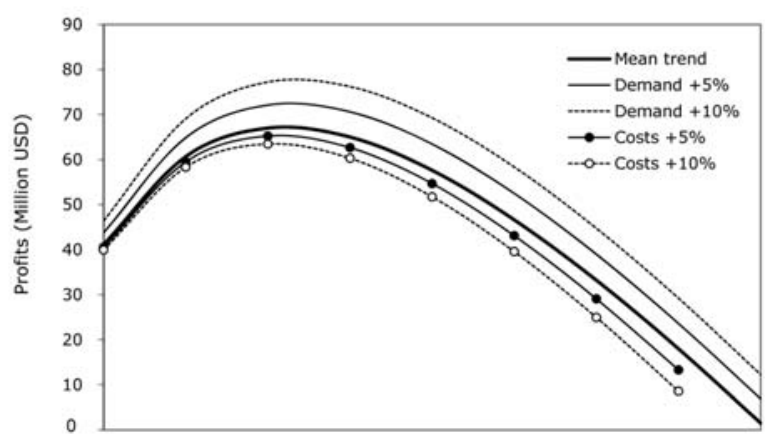

b)

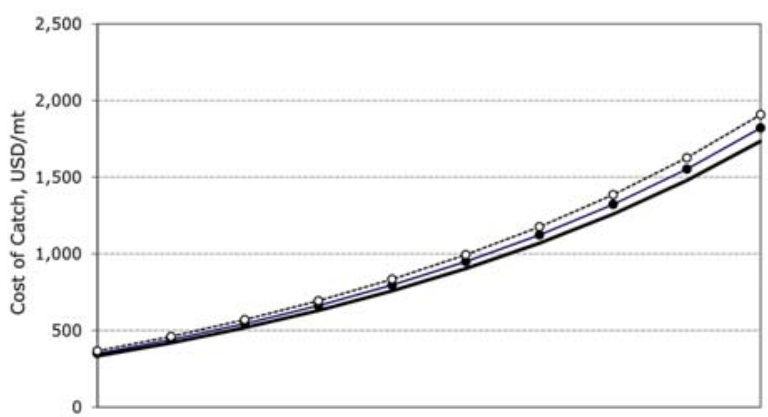

c)

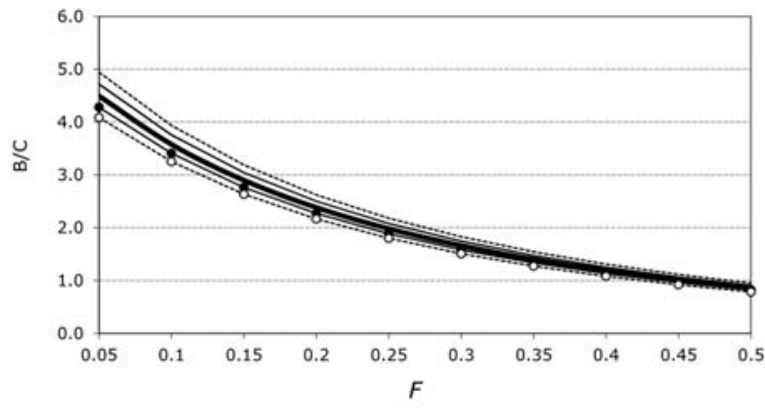

Figure 3. a) Potential profits as a function of $F$; b) Cost of fishing as a function of $F$; c) Benefit/Cost ratio as a function of $F / a$ ) Utilidades potenciales en función de la $F ; b$ ) Costo de la pesca en función de la $F$; c) Tasa Beneficio/Costo en función de la $F$ 
current levels, this fishery is economically inefficient and a significant reduction of $F$ should be applied to achieve the $M E Y$. Thus, for a management regime to ensure that juveniles reach maturity to maintain the population, the current fishing condition need to be changed, because it has been shown that the size of sexual maturity is strongly correlated with growth, the maximum size, and longevity (Froese \& Binohlan 2000). The simulation analysis also suggests that with reasonably low levels of fishing mortality below the MSY level, the population can support a moderate exploitation of juveniles without being exhausted. Care should be taken to avoid overfishing of recruits, which could have adverse effects on the population by reducing the spawning stock (Pauly et al. 1989).

Exploitation of fisheries evidences the complexity of translating the management regulation in the traditional context of single-species view to the ecosystem-based management, because of the multiple factors involved in the problem of conservation of the integrity of ecosystem trying to achieve social and economic benefits (García et al. 2011), even if evolutionary pressure is ignored. This consideration evidences the inadequacy of the single species-based based theory to deal with complex ecosystems. Despite all of these constrains, this approach must be in use until other more effective management tools are developed.

Fluctuation in the stock biomass is probably caused by environmental changes and their effect on catchability. Because the longevity of bigeye, the numbers in the population are not likely to change dramatically over a short time as often happens with short-lived species like the sardine. The IATTC indicates that there is a recent trend of increased biomass of bigeye tuna in the EPO, which could be caused by conservation measures implemented since 2004 (FSR 2010). The implementation of some area closures has been considered feasible to reduce the catch of bigeye and thus ensure sustainable fisheries (Harley \& Suter 2007), and the inclusion of amendments in the art (Maunder 2007), but according to the results of this study, it would be premature to implement those changes, and for the moment it is not perceived that this stock is threatened by over fishing. To obtain the MSY, is necessary to increase the $F$ from the current value of 0.249 to 0.29 , and to exploit the stock at the $M E Y$, it should be necessary to reduce $F$ from 0.249 to 0.16 . This reduction might be interpreted as an extreme reduction of fishing effort, but the economic returns would justify the change, because the profits would increase significantly respecting to the current $F$ or the
$F_{M S Y^{*}}$ Current profits are almost $\$ 58 \mathrm{M} \mathrm{USD}$, and at the $F_{M S Y}$ they would decrease to almost \$47 M USD; however, at the $F_{M E Y}$ a spectacular increase in profits of over $\$ 67 \mathrm{M}$ USD would be obtained, which could be used to invest outside this activity to provide jobs to the 665 fishermen that could have to leave this fishery. These results are consistent with Grafton et al. (2010, 2012), Kompas et al. (2010), and Kompas \& Che (2012), who stated that the biomass at the $F_{M E Y}$ level exceeds the biomass at the $F_{M S Y}$. In the case of the big eye tuna fishery, the biomass at the $F_{M E Y}$ is about $20 \%$ above the $F_{M S Y}$, despite that some warnings and assumptions should be considered (Dichmont 2010, Kompas \& Che 2012). These results and other trials made with the model applied to other artisanal fisheries provide similar outcome. The Christensen (2010) statement that the surplus economic benefits that can be obtained by reducing fishing intensity from the MSY level to the $M E Y$, can't be enough to fulfill the need of new jobs for the fishermen left out of the fishery, would be acceptable if the stock biomass would be not threatened by overfishing. In addition, should not be forgotten that fisheries exploited at the MSY level are very close of being overexploited, which is an undesirable risk and for this reason has been identified as a limit reference point (García 1994, Caddy \& Mahon 1995).

The IATTC has suggested the application of lower $F$ for the exploitation of bigeye tuna (FSR 2010). The results of our simulations suggest that the best harvesting strategy to adopt would be the $M E Y$, which implies several benefits and a few inconvenient social costs, which after a comparison with the current condition, seem to be quite acceptable. However, if this option is adopted, it would be convenient to apply it gradually to avoid undesirable social impact of a sudden change, because it would imply a reduction of nearly 665 fishermen from the current 3,517. The economic benefit would mean a significant increase from 57.8 M USD at the current condition to 67.1 M USD at the $M E Y$, showing that this surplus income could be used to finance other economic activities to provide employment for the fishermen leaving this activity. To minimize the social impact, the reduction of fishing effort should be made over several years. Taking the fishery to these levels, it is more likely to capture individuals at good sizes and there would be major economic gains in biomass (Froese 2004). An appropriate harvest regime would decrease the mortality of juveniles (Froese et al. 2008), which would reduce the impact of fishing on the population, generate higher stability in landings (Hsieh et al. 2006), and benefits to the ecosystem (Pikitch et al. 2004). 


\section{ACKNOWLedgments}

Two anonymous referees made valuable criticisms and suggestions. Financial support for F. Escobar-Toledo is given by a postgrade scholarship from National Council of Science and Technology (CONACyT) and the Institutional Program of Research Training (PIFI-IPN). F. Escobar-Toledo is grateful for the support received from the project 1117-489-25529. S. Ortega-García and E. A. Chávez hold a Grant from EDI and COFAA, IPN.

\section{LITERATURE CITED}

Aires-da-Silva A \& MN Maunder. 2010. Status of bigeye tuna in the eastern Pacific Ocean in 2009 and outlook for the future. Inter-American Tropical Tuna Commission, Stock Assessment Report 10: 116-228.

Bascompte J, CJ Mellán \& E Sala. 2005. Interaction strength combinations and the overfishing of a marine food web. Proceedings of the National Academy of Sciences 102(15): 5443-5447.

Beverton RJH \& SJ Holt. 1957. On the dynamics of exploited fish populations. U.K. Ministry of Agriculture and Fisheries, Fishery Investigations (Series II) 19: 1-533.

Caddy JF \& R Mahon. 1995. Reference points for fisheries management. FAO Fisheries Technical Paper 347: 1-83.

Chávez EA. 1995. La mortalidad natural y su relación con la longevidad y la tasa de crecimiento. Jaina 6(2): 3.

Chávez EA. 1996. Simulating fisheries for the assessment of optimum harvesting strategies. Naga ICLARM 19(2): 3335.

Chávez EA. 2005. FISMO: A generalized fisheries simulation model. In: Kruse GH, VF Gallucci, DE Hay, RI Perry, RM Peterman, TC Shirley, PD Spencer, B Wilson \& D Woodby (eds). Fisheries assessment and management in data-limited situations, pp. 659-681. Alaska Sea Grant College Program, University of Alaska Fairbanks, Fairbanks.

Compeán G. 2010. Informe de la reunión Científica de la Comisión Interamericana del Atún Tropical, 25 pp. InterAmerican Tropical Tuna Commission (IATTC), La Jolla.

Christensen V. 2010. MEY = MSY. Fish and Fisheries 11: 105-110.

Dichmont CM, S Pascoe, T Kompas, AE Punt \& R Deng. 2010. On implementing maximum economic yield in commercial fisheries. Proceedings of the National Academy of Science of the United States 107(1): 1-21.

Froese R. 2004. Keep it simple: three indicators to deal with overfishing. Fish and Fisheries 5: 86-91.

Froese R \& C Binohlan. 2000. Empirical relationships to estimate asymptotic length, length at first maturity and length at maximum yield per recruit in fishes, with a simple method to evaluate length frequency data. Journal of Fish Biology 56: 758-773.
Froese R, A Stern-Pirlot, H Winker \& D Gascuel. 2008. Size matters: How single-species management can contribute to ecosystem-based fisheries management. Fisheries Research 92: 231-241.

FSR. 2010. Tunas and billfishes in the Eastern Pacific Ocean in 2009. Fishery Status Report 8: 1-67. Inter-American Tropical Tuna Commission, La Jolla.

García SM. 1994. The precautionary principle: its implications in capture fisheries management. Ocean Coast and Management 22: 99-125.

García SM, J Kolding, J Rice, MJ Rochet, S Zhou, T Arimoto, J Beyer, L Borges, A Bundy, D Dunn, N Graham, M Hall, M Heino, R Law, M Makino, AD Rijnsdorp, AF Simard, ADM Smith \& D Symons. 2011. Selective fishing and balanced harvest in relation to fisheries and ecosystem sustainability. Report of a Scientific Workshop, IUCN-CEM Fisheries Expert Group (FEG) / European Bureau for Conservation and Development (EBCD), Nagoya, Japan, 14-16 October 2010: IUCN and EBCD Gland, Switzerland and Brussels, Belgium, 33 pp.

Grafton R, T Kompas, L Chu \& N Che. 2010. Maximum economic yield. The Australian Journal of Agricultural and Resource Economics 54: 273-280.

Gislason H, N Naan \& J Pope. 2010. Size, growth, temperature and the natural mortality rate of marine fish. Fish and Fisheries 11: 149-158.

Grafton QR, T Kompas, TN Che, L Chu \& R Hilborn. 2012. $B_{M E Y}$ as a fisheries management target. Fish and Fisheries 13: 303-312.

Harley SJ \& MN Maunder. 2005. Status of bigeye tuna in the eastern Pacific Ocean. Inter-American Tropical Tuna Commission Stock Assessment Report 4: 120-286.

Harley SJ \& JM Suter. 2007. The potential use of time-area closures to reduce catches of bigeye tuna (Thunnus obesus) in the purse-seine fishery of the eastern Pacific Ocean. Fishery Bulletin 105: 49-61.

Hilborn R \& C Walters. 1992. Quantitative fisheries stock assessment: Choice, dynamics and uncertainty, 570 pp. Chapman \& Hall, New York and London.

Hsieh CH, CS Reiss, JR Hunter, JR Beddington, RM May \& G Sugihara. 2006. Fishing elevates variability in the abundance of exploited species. Nature 443: 859-862.

IATTC. 2008. The fishery for tunas and billfishes in the Eastern Pacific Ocean in 2007. IATTC Document IATTC-78-05, IATTC 78th Meeting 23-27 June 2008, Panama,106 pp.

IATTC. 2010. Scientific Meeting Report, 31 August - 3 September, 2010, 31 pp. IATTC, La Jolla. <http:// www.iattc.org/Meetings/Meetings2010/PDF/Aug/SAC-01Meeting-report.pdf>

ISSF. 2010. Status of the world fisheries for tuna. 2010, Update on the status of the tuna stocks in the Eastern Pacific Ocean (EPO), 6 pp. International Seafood Sustainability Foundation, McLean, Virginia. 
Jensen AL. 1996. Beverton and Holt life history invariants result from optimal trade-off of reproduction and survival. Canadian Journal of Fisheries and Aquatic Sciences 53: 820-822.

Jensen AL. 1997. Origin of the relation between K and Linf and synthesis of relations among life history parameters. Canadian Journal of Fisheries and Aquatic Sciences 54: 987989.

Kompas T \& TN Che. 2012. Economic profit and optimal effort in the western and central Pacific tuna fisheries. Pacific Economic Bulletin, MOW1-IP/11 21: 45-62.

Kompas T, RQ Grafton \& TN Che. 2010. Bioeconomic losses from overharvesting tuna. Conservation Letters 3(3): 177183.

Lennert-Cody CE, JJ Roberts \& RJ Stephenson. 2007. An analysis of gear effects on the presence of bigeye tuna (Thunnus obesus) in the catches of the purse-seine fishery in the Eastern Pacific Ocean. $8^{\mathrm{TH}}$ Meeting Working Group to Review Stock Assessments. Document SAR-8-09c, 19 pp.

Maunder MN. 2007. Report from the workshop on management strategies, IATTC, La Jolla, California, 17-20 October 2006, 16 pp.

Maunder MN \& GM Watters. 2003. A-SCALA: an agestructured statistical catch-at-length analysis for assessing tuna stocks in the eastern Pacific Ocean. Bulletin InterAmerican Tropical Tuna Commission. 22: 433-582.

Maunder MN \& SD Hoyle. 2006. Status of bigeye tuna in the eastern Pacific Ocean. Stock Assessment Report 6. InterAmerican Tropical Tuna Commission. La Jolla, California, pp. 103-178.

Maunder MN \& SJ Harley. 2007. Evaluating tuna management in the Eastern Pacific Ocean. Bulletin of Marine Science 78(3): 593-606.
Mora G. 1997. La pesca en cifras. ATUNEC. <http:// www.fis.com/atunec/cifrasfr.htm>

Nakamura EL \& JH Uchiyama. 1966. Length-weight relations of Pacific tunas. In: Manar TA (ed). Proceedings, Governor's Conference on Central Pacific Fishery Resources Honolulu, pp. 197-201.

Pauly D. 1983. Algunos métodos simples para la evaluación de recursos pesqueros tropicales. FAO Documento Técnico de Pesca 234: 1-49.

Pauly D, G Silvestre \& IR Smith. 1989. On development, fisheries and dynamite: A brief review of tropical fisheries management. Natural Resource Modelling 3(3): 307-329.

Pikitch EK, C Santora, EA Babcock, A Bakun, R Bonfil, DO Conover, P Dayton, P Doukaskis, D Fluharty, B Heneman, ED Houde, J Link, PA Livingston, M Mangel, MK McAllister, J Pope \& KJ Sainsbury. 2004. Ecosystem-based fishery management. Science 305: 346347.

Shin YJ, MJ Rochet, S Jennings, JG Field \& H Gislason. 2005. Using size-based indicators to evaluate the ecosystem effects of fishing. ICES Journal of Marine Science 62: 384396.

Sparre P \& S Venema. 1997. Introduction to tropical fish stock assessment. Part 1. Manual. FAO Fisheries Technical Paper 306/1: 1-420.

Trexler J \& J Travis. 2000. Can marine protected areas restore and conserve stock attributes of reef fishes? Bulletin of Marine Science 66(3): 853-873.

Vakily JM. 1992. Determination and comparison of bivalve growth, with emphasis on Thailand and other tropical areas. ICLARM Techincal Report 36: 1-125.

Zhu G, Y Zhou, L Xu \& X Dai. 2009. Growth and mortality of bigeye tuna Thunnus obesus (Scombridae) in the eastern and central tropical Pacific Ocean. Environmental Biology of Fishes 85(2): 127-137.

Received 11 April 2012 and accepted 11 April 2013

Associated Editor: Mauricio Landaeta D. 